\title{
Microwave-assisted synthesis of 5,6-dihydroindolo[1,2-a]quinoxaline derivatives through copper-catalyzed intramolecular $\mathbf{N}$-arylation
}

\author{
Fei Zhao, Lei Zhang, Hailong Liu, Shengbin Zhou and Hong Liu*
}

\author{
Full Research Paper \\ Address: \\ CAS Key Laboratory of Receptor Research, Shanghai Institute of \\ Materia Medica, Chinese Academy of Sciences, 555 Zuchongzhi \\ Road, Shanghai 201203, P. R. China \\ Email: \\ Hong Liu* - hliu@mail.shcnc.ac.cn \\ ${ }^{*}$ Corresponding author \\ Keywords: \\ copper; 5,6-dihydroindolo[1,2-a]quinoxaline; intramolecular \\ $\mathrm{N}$-arylation; microwave irradiation
}

\author{
Beilstein J. Org. Chem. 2013, 9, 2463-2469. \\ doi:10.3762/bjoc. 9.285 \\ Received: 17 July 2013 \\ Accepted: 12 October 2013 \\ Published: 14 November 2013 \\ Associate Editor: J. Aubé \\ (c) 2013 Zhao et al; licensee Beilstein-Institut. \\ License and terms: see end of document.
}

\begin{abstract}
An efficient and practical protocol has been developed to synthesize 5,6-dihydroindolo[1,2-a]quinoxaline derivatives by CuIcatalyzed intramolecular $N$-arylation under microwave irradiation. This method rapidly afforded the tetracyclic products with good to excellent yields (83-97\%) in short reaction times (45-60 $\mathrm{min})$.
\end{abstract}

\section{Introduction}

The indole scaffold is considered as a privileged structure because of its ubiquitous presence in a large number of natural products and pharmaceutical agents [1-6]. In particular, indolefused heterocycles have received much attention because of their applications in medicinal chemistry [7-11]. Among them, the tetracyclic ring system of 5,6-dihydroindolo[1,2-a]quinoxalines forms an important class of compounds because of their diverse range of pharmacological properties (Figure 1). For example, compound A shows pronounced antihistaminic activity [12]. Compound $\mathbf{B}$ is identified as a promising antifungal reagent against phytopathogenic fungi in vitro [13], and both compounds $\mathbf{C}$ and $\mathbf{D}$ exhibit a good inhibitory activity against VEGFR-3 kinase cells [14]. Therefore, an efficient access to this fused tetracyclic architecture is highly desirable for drug discovery.

Traditional copper-catalyzed Ullmann-type C-N coupling has been a powerful method to form the carbon-nitrogen bond [1519]. However, the utility of the reaction is limited by the necessary high temperatures, the requirement of stoichiometric quantities of copper catalyst and low to moderate yields [20]. A recent breakthrough to overcome these drawbacks involves the use of appropriate ligands such as diamines and amino acids [21-24] that can enhance the activity of the copper catalysts and accelerate the reactions. As a result, the copper-catalyzed $\mathrm{N}$-arylation has been extensively utilized for C-N coupling, 


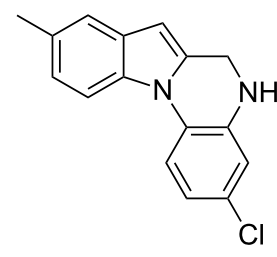

A

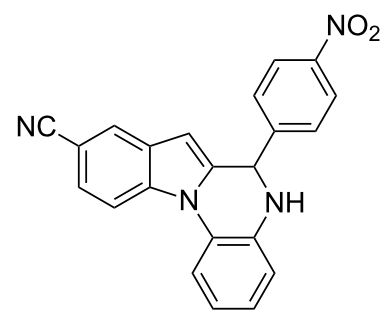

B

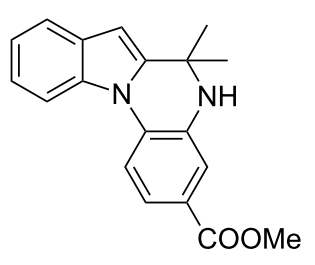

C

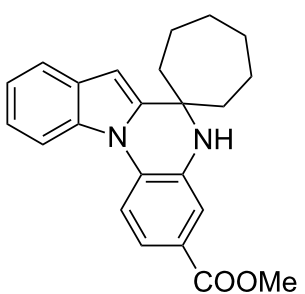

D

Figure 1: Representative biologically relevant examples of 5,6-dihydroindolo[1,2-a]quinoxaline derivatives.

especially for the arylation of $\mathrm{N}$-containing heterocycles such as indoles, imidazoles, indazoles, pyrroles, pyrazoles and triazoles [25-28] to construct more fused heterocycles.

In recent years, several approaches toward the synthesis of 5,6dihydroindolo[1,2- $a]$ quinoxaline derivatives have been reported [29-42]: (a) $\mathrm{Ru}-$ and Au-catalyzed cascade reactions between 2-(1H-indol-1-yl)anilines and alkynes [34,42]. (b) $\mathrm{AlCl}_{3}-$ catalyzed Pictet-Spengler reactions between 2-(1H-indol-1yl)anilines and aromatic aldehydes [38]. (c) Pd-catalyzed regioselective $\mathrm{C}-\mathrm{H}$ olefination/cyclization sequences from indole-substituted anilines and electron-deficient terminal alkenes [37]. However, these methods require expensive metal catalysts, long reaction time and produce only moderate yields. In this study, we tried to overcome these limitations by using copper-catalyzed $\mathrm{C}-\mathrm{N}$ coupling and microwave-assisted organic synthesis, and we present an efficient and practical protocol, which rapidly synthesized 5,6-dihydroindolo[1,2$a$ ]quinoxaline derivatives by copper-catalyzed intramolecular $\mathrm{N}$-arylation with good to excellent yields.

\section{Results and Discussion}

The required cyclization precursors $\mathbf{1}$, aryl substituted $(1 H$ indol-2-yl)methanamines, were easily prepared by reductive amination of $1 H$-indole-2-carbaldehydes with 2-haloanilines in good yields (Scheme 1).

Initial screening experiments were performed by employing 1a as the model substrate in order to optimize the intramolecular cyclization conditions for ligands, bases, solvents, temperature and time. As shown in Table 1, the reaction was initially carried out with $\mathrm{CuI}$ as the catalyst, $\mathbf{L 1}$ as the ligand, and $\mathrm{K}_{3} \mathrm{PO}_{4}$ as the base in toluene at $110{ }^{\circ} \mathrm{C}$ heated in an oil bath for $10 \mathrm{~h}$. Unfortunately, most of the substrate 1a was recovered (Table 1, entry 1) and the desired product was obtained only in low yield $(38 \%)$. Considering that microwave-assisted organic synthesis (MAOS) is time- and energy-saving [43-45], we then chose this technology to conduct the intramolecular $N$-arylation. As a result, a similar yield was obtained under the same catalytic conditions when 1a was subjected to microwave irradiation for just one hour (Table 1, entry 2). Then, we tried to optimize the<smiles></smiles><smiles>[X]c1ccc(N)c([X])c1</smiles>

$R^{2}$ $a, b$<smiles>[R]c1ccccc1NCc1cc2cc[R1]cc2[nH]1</smiles> 
Table 1: Optimization of the reaction conditions for the Cu-catalyzed synthesis of 5,6-dihydroindolo[1,2-a]quinoxaline $(2 a){ }^{a}$

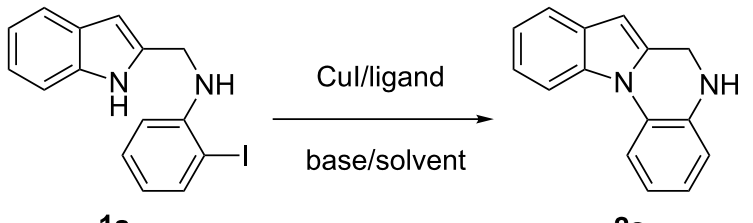

$1 a$

$2 a$

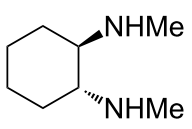

L1<smiles>N[C@@H]1CCCC[C@H]1N</smiles>

L2<smiles>NCCN</smiles>

L3<smiles>CNCCNC</smiles>

L4

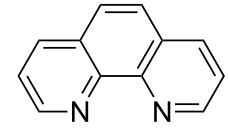

L5<smiles>O=C(O)C1CCCN1</smiles>

L6

\begin{tabular}{|c|c|c|c|c|}
\hline entry & ligand & base & solvent/temperature/time & yield $(\%)^{b}$ \\
\hline $1^{c}$ & L1 & $\mathrm{K}_{3} \mathrm{PO}_{4}$ & toluene $/ 110^{\circ} \mathrm{C} / 10 \mathrm{~h}$ & $38^{d}$ \\
\hline 2 & L1 & $\mathrm{K}_{3} \mathrm{PO}_{4}$ & toluene $/ 110^{\circ} \mathrm{C} / 1 \mathrm{~h}$ & $36^{d}$ \\
\hline 3 & L2 & $\mathrm{K}_{3} \mathrm{PO}_{4}$ & toluene $/ 110^{\circ} \mathrm{C} / 1 \mathrm{~h}$ & $35^{d}$ \\
\hline 4 & L3 & $\mathrm{K}_{3} \mathrm{PO}_{4}$ & toluene $/ 110^{\circ} \mathrm{C} / 1 \mathrm{~h}$ & $10^{d}$ \\
\hline 5 & L4 & $\mathrm{K}_{3} \mathrm{PO}_{4}$ & toluene $/ 110^{\circ} \mathrm{C} / 1 \mathrm{~h}$ & trace $^{d}$ \\
\hline 6 & L5 & $\mathrm{K}_{3} \mathrm{PO}_{4}$ & toluene $/ 110^{\circ} \mathrm{C} / 1 \mathrm{~h}$ & trace $^{d}$ \\
\hline 7 & L6 & $\mathrm{K}_{3} \mathrm{PO}_{4}$ & toluene $/ 110^{\circ} \mathrm{C} / 1 \mathrm{~h}$ & 52 \\
\hline 8 & L6 & $\mathrm{K}_{3} \mathrm{PO}_{4}$ & toluene $/ 90^{\circ} \mathrm{C} / 1 \mathrm{~h}$ & 58 \\
\hline 9 & L6 & $\mathrm{K}_{3} \mathrm{PO}_{4}$ & 1,4-dioxane $/ 90^{\circ} \mathrm{C} / 1 \mathrm{~h}$ & 64 \\
\hline 10 & L6 & $\mathrm{K}_{3} \mathrm{PO}_{4}$ & $\mathrm{CH}_{3} \mathrm{CN} / 90^{\circ} \mathrm{C} / 1 \mathrm{~h}$ & 72 \\
\hline 11 & L6 & $\mathrm{K}_{3} \mathrm{PO}_{4}$ & $\mathrm{DMSO} / 90^{\circ} \mathrm{C} / 1 \mathrm{~h}$ & 85 \\
\hline 12 & L6 & $\mathrm{K}_{2} \mathrm{CO}_{3}$ & $\mathrm{DMSO} / 90^{\circ} \mathrm{C} / 1 \mathrm{~h}$ & 92 \\
\hline 13 & L6 & $\mathrm{Cs}_{2} \mathrm{CO}_{3}$ & $\mathrm{DMSO} / 90^{\circ} \mathrm{C} / 1 \mathrm{~h}$ & 88 \\
\hline 14 & L6 & $\mathrm{K}_{2} \mathrm{CO}_{3}$ & $\mathrm{DMSO} / 90^{\circ} \mathrm{C} / 45 \mathrm{~min}$ & 92 \\
\hline 15 & L6 & $\mathrm{K}_{2} \mathrm{CO}_{3}$ & $\mathrm{DMSO} / 90^{\circ} \mathrm{C} / 30 \mathrm{~min}$ & 80 \\
\hline
\end{tabular}

aUnless noted, reactions were performed with 1a $(0.25 \mathrm{mmol})$, Cul $(0.025 \mathrm{mmol})$, ligand $(0.05 \mathrm{mmol})$, and base $(0.5 \mathrm{mmol})$ in solvent $(2 \mathrm{~mL})$ at the indicated temperature under microwave irradiation (sealed vessel at fixed power, $30 \mathrm{~W}$ ). ${ }^{\mathrm{b}}$ Isolated yield. ${ }^{\mathrm{CH}}$ Heated with oil bath. ${ }^{\mathrm{d}} \mathbf{1 a}$ was recovered.

reaction conditions under microwave heating. At first, various ligands were evaluated. Among them, L6 was the most effective ligand for the $N$-arylation (Table 1, entries 3-7). Because of the deiodination of the reactant, product 2a was obtained only in moderate yield (52\%). Therefore, to eliminate the deiodination byproduct, we decreased the reaction temperature to $90{ }^{\circ} \mathrm{C}$, and a slightly higher yield was obtained (Table 1, entry 8 ). With L-proline as the best ligand, a further screening of the solvents revealed that increasing the polarity of the solvent had a positive effect on the reaction yield, and DMSO displayed as the best choice to promote the transformation with $85 \%$ yield (Table 1, entries 9-11). Next, an examination of the bases revealed that the moderately strong base $\mathrm{K}_{2} \mathrm{CO}_{3}$ produced the best yield $(92 \%)$, both a weaker base $\left(\mathrm{K}_{3} \mathrm{PO}_{4}\right)$ and a stronger base $\left(\mathrm{Cs}_{2} \mathrm{CO}_{3}\right)$ resulted in decreased yields (Table 1, entries 11-13). In addition, a study of the reaction time proved that 45 minutes was just enough to complete the transformation with an excellent yield (Table 1, entry 14), while a further reduction of the reaction time led to a decreased yield (Table 1, entry 15).
In this way, the optimal reaction conditions were identified to be the catalytic system of $\mathrm{CuI} / \mathrm{L}$-proline $/ \mathrm{K}_{2} \mathrm{CO}_{3}$ in $\mathrm{DMSO}$ under microwave irradiation for 45 minutes.

After determining the optimal reaction conditions, we then examined the general applicability of the process. First, the substituents of the indole moiety were explored (Table 2). Halogens $(\mathrm{F}, \mathrm{Cl}, \mathrm{Br})$ were tolerated well and high yields (93-94\%) were obtained (Table 2, entries 2-4). The substrate with an electron-withdrawing nitro group also afforded the product with an excellent yield (97\%) within 45 minutes (Table 2, entry 5). The protocol was also compatible with substrates with electrondonating substituents such as methyl and methoxy groups (Table 2, entries 6 and 7) which achieved high yields (90-91\%) within one hour to have the substrates completely consumed. We attributed this to the weakened acidity of the indole $\mathrm{NH}$, which is caused by the electron-donating substituents. In particular, antihistamine reagent $\mathbf{A}$ (2a) was synthesized in a total yield of $67 \%$ (Table 2, entry 8), while it took four steps to 
Table 2: Synthesis of 5,6-dihydroindolo[1,2-a]quinoxalines by Cul-catalyzed intramolecular $\mathrm{N}$-arylation. ${ }^{\text {a }}$

entry

$1 \mathrm{a}$

substrate

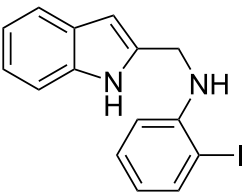

$1 b$<smiles>Fc1ccc2[nH]c(CNc3ccccc3I)cc2c1</smiles><smiles>Clc1ccc2[nH]c(CNc3ccccc3I)cc2c1</smiles>

4

3

1c<smiles>Brc1ccc2[nH]c(CNc3ccccc3I)cc2c1</smiles>

5<smiles>O=[N+]([O-])c1ccc2[nH]c(CNc3ccccc3I)cc2c1</smiles>

$6^{c}$<smiles>COc1ccc2[nH]c(CNc3ccccc3I)cc2c1</smiles>

$7^{c}$<smiles>Cc1ccc2[nH]c(CNc3ccccc3I)cc2c1</smiles><smiles>Cc1ccc2[nH]c(CNc3cc(Cl)ccc3I)cc2c1</smiles><smiles>FC(F)(F)c1ccc(NCc2cc3ccccc3[nH]2)c(I)c1</smiles>

product

yield $(\%)^{b}$

$2 a$<smiles>c1ccc2c(c1)NCc1cc3ccccc3n1-2</smiles>

$2 b$<smiles>Fc1ccc2c(c1)cc1n2-c2ccccc2NC1</smiles>

94

2c<smiles>Clc1ccc2c(c1)cc1n2-c2ccccc2NC1</smiles>

93

2d<smiles>Brc1ccc2c(c1)cc1n2-c2ccccc2NC1</smiles>

94

$2 e$<smiles>O=[N+]([O-])c1ccc2c(c1)cc1n2-c2ccccc2NC1</smiles>

$2 f$<smiles>COc1ccc2c(c1)cc1n2-c2ccccc2NC1</smiles>

$2 g$<smiles>Cc1ccc2c(c1)cc1n2-c2ccccc2NC1</smiles>

2h<smiles>Cc1ccc2c(c1)cc1n2-c2ccc(Cl)cc2NC1</smiles>

$2 \mathbf{i}$<smiles>FC(F)(F)c1ccc2c(c1)-n1c(cc3ccccc31)CN2</smiles>

97

90

91

92

96 
Table 2: Synthesis of 5,6-dihydroindolo[1,2-a]quinoxalines by Cul-catalyzed intramolecular $\mathrm{N}$-arylation. ${ }^{\text {a }}$ (continued) $^{2}$

10

1j

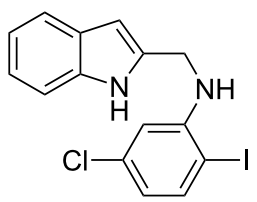

11

$1 \mathrm{k}$

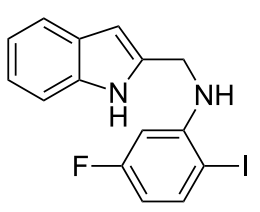

11

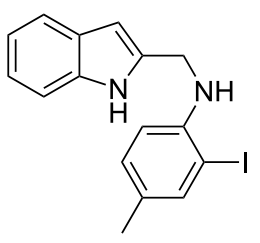

$1 \mathrm{~m}$

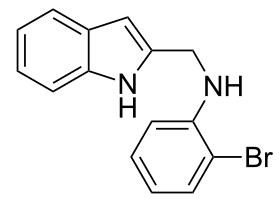<smiles>Clc1ccc(NCc2cc3ccccc3[nH]2)c(Br)c1</smiles>

10

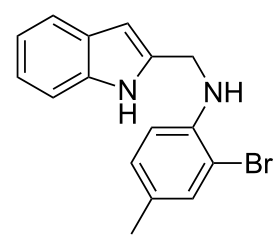

$1 p$



$16^{d}$$$
1 p
$$

2j<smiles>Clc1ccc2c(c1)NCc1cc3ccccc3n1-2</smiles>

95

91

88<smiles>Fc1ccc2c(c1)NCc1cc3ccccc3n1-2</smiles>

21<smiles>Cc1ccc2c(c1)-n1c(cc3ccccc31)CN2</smiles>

85 84

83

86
$2 a$<smiles>c1ccc2c(c1)NCc1cc3ccccc3n1-2</smiles>

$2 n$<smiles>Cc1ccc2c(c1)-n1c(cc3ccccc31)CN2</smiles>

Cl<smiles>Cc1ccc2c(c1)-n1c(cc3ccccc31)CN2</smiles>

2k

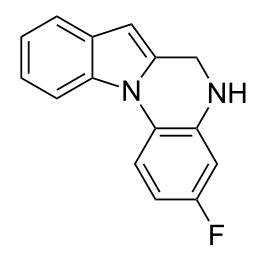

1

88

aUnless noted, reactions were performed with $1(0.25 \mathrm{mmol})$, Cul $(0.025 \mathrm{mmol})$, L-proline $(0.05 \mathrm{mmol})$ and $\mathrm{K}_{2} \mathrm{CO}_{3}(0.5 \mathrm{mmol})$ in DMSO $(2 \mathrm{~mL})$ at $90^{\circ} \mathrm{C}(\mathrm{MW}$ irradiation, sealed vessel at fixed power, $30 \mathrm{~W})$. ${ }^{\mathrm{b}}$ Isolated yield. ${ }^{\mathrm{c}}$ The reaction was run for one hour. ${ }^{\mathrm{d}}$ The reaction was performed at $140{ }^{\circ} \mathrm{C}$ with $\mathrm{Cs}_{2} \mathrm{CO}_{3}$ as the base for one hour.

afford this molecule with only $24 \%$ total yield in the original literature [12].

Next, the approach was investigated with respect to the structural variation of the aryl iodide moiety. The reaction proceeded smoothly with high yields for substrates with electron deficient aryl iodides, whereas methyl-substituted substrate $\mathbf{2 l}$ required additional 15 minutes to complete the transformation (Table 2, entries 9-12). This indicated that electron-deficient aryl iodides display a better reactivity than electron-rich ones. A further 
extension of the methodology to various substrates linked with bromobenzene was also briefly investigated. In light of a lower reactivity of bromobenzenes compared to iodobenzenes in $\mathrm{C}-\mathrm{N}$ coupling reactions, we replaced $\mathrm{K}_{2} \mathrm{CO}_{3}$ with the stronger base $\mathrm{Cs}_{2} \mathrm{CO}_{3}$, and elevated the reaction temperature from $90{ }^{\circ} \mathrm{C}$ to $140{ }^{\circ} \mathrm{C}$. As a result, all these bromo-substituted substrates provided the desired products with good yields within one hour (Table 2, entries 13-16). These findings broadened the substrate scope of the methodology.

\section{Conclusion}

In summary, we have developed a simple and efficient CuIcatalyzed methodology for the synthesis of 5,6-dihydroindolo $[1,2-a]$ quinoxaline derivatives. This approach rapidly achieved the tetracyclic products with good to excellent yields in short reaction time under microwave irradiation. We anticipate that these important heterocyclic compounds that incorporate the bioactive indole motif may find their pharmaceutical applications after further investigations.

\section{Experimental}

General procedure for the synthesis of 5,6-dihydroindolo[1,2$a$ ]quinoxalines: A high-pressure microwave vessel was loaded with 1 ( $0.25 \mathrm{mmol}, 1.0$ equiv), $\mathrm{CuI}(0.025 \mathrm{mmol}, 4.8 \mathrm{mg}$, 0.1 equiv), L-proline ( $0.05 \mathrm{mmol}, 5.8 \mathrm{mg}, 0.2$ equiv), and the base indicated ( $0.5 \mathrm{mmol}, 2.0$ equiv) in DMSO $(2 \mathrm{~mL})$. The vessel was degassed, refilled with argon, and sealed. The mixture was heated to the temperature indicated for the indicated time under microwave irradiation (fixed power, $30 \mathrm{~W}$ ). After cooling, the reaction mixture was washed with water, and then extracted with ethyl acetate. The organic extracts were washed with brine, dried over $\mathrm{Na}_{2} \mathrm{SO}_{4}$, and concentrated. The residue was purified by flash chromatography (petroleum ether/EtOAc 16:1 as eluent) to give 2 .

\section{Supporting Information}

\section{Supporting Information File 1}

General information, experimental details, characterization data and copies of ${ }^{1} \mathrm{H}$ and ${ }^{13} \mathrm{C}$ NMR spectra.

[http://www.beilstein-journals.org/bjoc/content/ supplementary/1860-5397-9-285-S1.pdf]

\section{Acknowledgements}

We gratefully acknowledge financial support from the National Natural Science Foundation of China (Grants 21021063, 91229204, and 81025017), National S\&T Major Projects (2012ZX09103101-072 and 2012ZX09301001005).

\section{References}

1. Kochanowska-Karamyan, A. J.; Hamann, M. T. Chem. Rev. 2010, 110, 4489-4497. doi:10.1021/cr900211p

2. Sundberg, R. J.; Smith, S. Q. The IBOGA alkaloids and their role as precursors of anti-neoplastic bisindole catharanthus alkaloids; The Alkaloids: Chemistry and Biology, Vol. 59; Academic Press, 2002; pp 281-376. doi:10.1016/S0099-9598(02)59009-X

3. Newhouse, T.; Lewis, C. A.; Eastman, K. J.; Baran, P. S. J. Am. Chem. Soc. 2010, 132, 7119-7137. doi:10.1021/ja1009458

4. Aygun, A.; Pindur, U. Curr. Med. Chem. 2003, 10, 1113-1127. doi:10.2174/0929867033457511

5. de Sá Alves, F. R.; Barreiro, E. J.; Fraga, C. A. Mini-Rev. Med. Chem. 2009, 9, 782-793. doi:10.2174/138955709788452649

6. Ishikura, M.; Yamada, K.; Abe, T. Nat. Prod. Rep. 2010, 27, 1630-1680. doi:10.1039/c005345g

7. Saxton, J. E. Nat. Prod. Rep. 1997, 14, 559-590. doi:10.1039/np9971400559

8. Humphrey, G. R.; Kuethe, J. T. Chem. Rev. 2006, 106, 2875-2911. doi:10.1021/cr0505270

9. Somei, M.; Yamada, F. Nat. Prod. Rep. 2005, 22, 73-103. doi:10.1039/b316241a

10. Bandini, M.; Eichholzer, A. Angew. Chem., Int. Ed. 2009, 48, 9608-9644. doi:10.1002/anie.200901843

11. Bonjoch, J.; Solé, D. Chem. Rev. 2000, 100, 3455-3482. doi:10.1021/cr9902547

12. Merwade, A. Y.; Rajur, S. B.; Basanagoudar, L. D. Indian J. Chem., Sect. B 1990, 29, 1113-1117.

13. Xu, H.; Fan, L.-L. Eur. J. Med. Chem. 2011, 46, 1919-1925. doi:10.1016/j.ejmech.2011.02.035

14. Lin, P.-T.; Salunke, D. B.; Chen, L.-H.; Sun, C.-M. Org. Biomol. Chem. 2011, 9, 2925-2937. doi:10.1039/c0ob01126f

15. Ullmann, F. Ber. Dtsch. Chem. Ges. 1903, 36, 2382-2384. doi:10.1002/cber.190303602174

16. Lindley, J. Tetrahedron 1984, 40, 1433-1456. doi:10.1016/S0040-4020(01)91791-0

17. Ullmann, F. Ber. Dtsch. Chem. Ges. 1904, 37, 853-854. doi:10.1002/cber.190403701141

18. Liu, Y.; Wan, J.-P. Org. Biomol. Chem. 2011, 9, 6873-6894. doi:10.1039/c1ob05769c

19. Liu, Y.; Wan, J.-P. Chem.-Asian J. 2012, 7, 1488-1501. doi:10.1002/asia.201101063

20. Sawyer, J. S. Tetrahedron 2000, 56, 5045-5065. doi:10.1016/S0040-4020(00)00257-X

21. Antilla, J. C.; Klapars, A.; Buchwald, S. L. J. Am. Chem. Soc. 2002, 124, 11684-11688. doi:10.1021/ja027433h

22. Ma, D.; Cai, Q.; Zhang, H. Org. Lett. 2003, 5, 2453-2455. doi:10.1021/ol0346584

23. Goodbrand, H. B.; Hu, N.-X. J. Org. Chem. 1999, 64, 670-674. doi:10.1021/jo981804o

24. Zhang, H.; Cai, Q.; Ma, D. J. Org. Chem. 2005, 70, 5164-5173. doi:10.1021/jo0504464

25. Antilla, J. C.; Baskin, J. M.; Barder, T. E.; Buchwald, S. L. J. Org. Chem. 2004, 69, 5578-5587. doi:10.1021/jo049658b

26. Hosseinzadeh, R.; Tajbakhsh, M.; Alikarami, M.; Mohadjerani, M. J. Heterocycl. Chem. 2008, 45, 1815-1818. doi:10.1002/jhet.5570450640

27. Rao, R. K.; Naidu, A. B.; Jaseer, E. A.; Sekar, G. Tetrahedron 2009, 65, 4619-4624. doi:10.1016/j.tet.2009.03.061

28. Jitchati, R.; Batsanov, A. S.; Bryce, M. R. Tetrahedron 2009, 65, 855-861. doi:10.1016/j.tet.2008.11.036 
29. Agarwal, P. K.; Sawant, D.; Sharma, S.; Kundu, B. Eur. J. Org. Chem. 2009, 292-303. doi:10.1002/ejoc.200800929

30. Patil, N. T.; Mutyala, A. K.; Lakshmi, P. G. V. V.; Raju, P. V. K.; Sridhar, B. Eur. J. Org. Chem. 2010, 10, 1999-2007. doi:10.1002/ejoc.200901364

31. Rustagi, V.; Tiwari, R.; Verma, A. K. Eur. J. Org. Chem. 2012, 4590-4602. doi:10.1002/ejoc.201200546

32. Rustagi, V.; Aggarwal, T.; Verma, A. K. Green Chem. 2011, 13, 1640-1643. doi:10.1039/c1gc15346c

33. Yi, C. S.; Yun, S. Y. J. Am. Chem. Soc. 2005, 127, 17000-17006. doi:10.1021/ja055608s

34. Patil, N. T.; Kavthe, R. D.; Shinde, V. S.; Sridhar, B. J. Org. Chem. 2010, 75, 3371-3380. doi:10.1021/jo100373w

35. Maiti, B.; Sun, C.-M. New J. Chem. 2011, 35, 1385-1396. doi:10.1039/c1nj20153k

36. Lai, J.-J.; Salunke, D. B.; Sun, C.-M. Org. Lett. 2010, 12, 2174-2177. doi:10.1021/ol100436r

37. Wang, L.; Guo, W.; Zhang, X.-X.; Xia, X.-D.; Xiao, W.-J. Org. Lett. 2012, 14, 740-743. doi:10.1021/ol203275b

38. Verma, A. K.; Jha, R. R.; Sankar, V. K.; Aggarwal, T.; Singh, R. P.; Chandra, R. Eur. J. Org. Chem. 2011, 6998-7010. doi:10.1002/ejoc.201101013

39. Biswas, S.; Singh, V.; Batra, S. Tetrahedron 2010, 66, 7781-7786. doi:10.1016/j.tet.2010.07.078

40. Patil, N. T.; Lakshmi, P. G. V. V.; Singh, V. Eur. J. Org. Chem. 2010, 4719-4731. doi:10.1002/ejoc.201000389

41. Liu, G.; Zhou, Y.; Lin, D.; Wang, J.; Zhang, L.; Jiang, H.; Liu, H. ACS Comb. Sci. 2011, 13, 209-213. doi:10.1021/co1000844

42. Zhou, Y.; Ji, X.; Liu, G.; Zhang, D.; Zhao, L.; Jiang, H.; Liu, H. Adv. Synth. Catal. 2010, 352, 1711-1717. doi:10.1002/adsc.201000199

43. Caddick, S.; Fitzmaurice, R. Tetrahedron 2009, 65, 3325-3355. doi:10.1016/j.tet.2009.01.105

44. Kappe, C. O.; Dallinger, D. Nat. Rev. Drug Discovery 2006, 5, 51-63. doi:10.1038/nrd1926

45. Kappe, C. O. Angew. Chem., Int. Ed. 2004, 43, 6250-6284. doi:10.1002/anie.200400655

\section{License and Terms}

This is an Open Access article under the terms of the Creative Commons Attribution License

(http://creativecommons.org/licenses/by/2.0), which permits unrestricted use, distribution, and reproduction in any medium, provided the original work is properly cited.

The license is subject to the Beilstein Journal of Organic Chemistry terms and conditions:

(http://www.beilstein-journals.org/bjoc)

The definitive version of this article is the electronic one which can be found at: doi:10.3762/bjoc. 9.285 